\author{
dr hab. Adam SADOWSKI, prof. UwB \\ Wydział Ekonomii i Zarządzania, Uniwersytet w Białymstoku \\ e-mail: adamsad@poczta.onet.pl \\ mgr Anna SZYDLIK \\ doktorantka na Wydziale Ekonomii i Zarządzania, Uniwersytet w Białymstoku \\ e-mail: a.szydlik1@wp.pl
}

DOI: $10.15290 /$ ose.2016.02.80.05

\title{
POZNANIE NAUKOWE I KANONY NAUKI
}

\begin{abstract}
Streszczenie
Nauka jest nie tylko procesem pozyskiwania wiedzy, ale również sposobem realizacji potrzeby poznawczej jednostki. Podstawowym jej celem jest tworzenie czegoś nowego. Poznanie naukowe przebiega w umyśle samego badacza, a jego kluczową cechą jest interdyscyplinarność.

Dyskusja na temat odróżniania poznania naukowego od nienaukowego jest aktualna zwłaszcza w dziedzinie nauk ekonomicznych. Celem artykułu jest analiza istoty poznania i wybranych kanonów naukowych w odniesieniu do ekonomii. Autorzy zakładają że stosowanie kanonów nauki i predyspozycje samego badacza determinują wynik procesów poznawczych. Opracowanie obejmuje opis pojeć, takich jak: poznanie, wyjaśnienie naukowe, rodzaje metod i procesów poznania naukowego, paradygmat. Ma to ułatwić rozwiązywanie problemów w sposób naukowy, przede wszystkim badaczom nauk ekonomicznych.
\end{abstract}

Słowa kluczowe: nauka, poznanie naukowe, kanony nauki, ekonomia

\section{ACQUISITION OF KNOWLEDGE AND CANONS OF SCIENCE}

\section{Summary}

Science is not only a process of knowledge acquisition, but also a way in which individuals fulfill their cognitive needs. Its main aim is creation, construction of something new. Scientific knowledge takes place in the mind of a researcher and its key feature is an interdisciplinary character. The debate on distinguishing scientific from non-scientific cognition is still valid, especially in the field of economic sciences. The aim of this paper is to analyze the essence of cognition and selected scientific canons with regard to economics. The author assumes that the use of the canons of science and the capacities of the researcher determine the outcome of cognitive processes. The study includes a description of such concepts as cognition, scientific explanation, types of methods and processes of scientific cognition, and paradigm. This is designed to make it easier to solve problems in a scientific manner, primarily for all the researchers in the field of economics.

Key words: science, acquisition of knowledge, canons of science, economics

JEL: B400, A10 
Poznanie nie zaczyna sie od postrzęęen zmystowych ani od obserwacii lub zbierania danych cäy tez faktón, lecz zaczyna sie od problemón.

K. R. Popper

\section{Wstęp}

Nauka to obszar wiedzy będący zbiorem wyników badań opartym na wcześniejszych założeniach innych badaczy. To również proces zdobywania wiedzy o: przyrodzie, istocie świata i kreowaniu jej w określonych warunkach społecznych. Jest ona procesem badawczym prowadzącym do uzyskania wiedzy racjonalnej, jak również systemem twierdzeń oraz hipotez dotyczących: człowieka, społeczeństwa i zjawisk gospodarczych. To jeden ze sposobów realizacji potrzeby poznawczej człowieka, w tym podziwu i ciekawości dla świata [Ajdukiewicz, 1985, s. 35].

Nie każda nowa wiedza posiada charakter naukowy. Obecnie największym problemem, stanowiącym przedmiot dyskusji naukowców, jest umiejętność odróżnienia nauki od pseudonauki. Przyjmuje się, że dana myśl posiada charakter naukowy, jeżeli ma na względzie kanony poznania naukowego.

Dyskusja dotycząca poznania i kanonów w nauce jest aktualna zwłaszcza w dziedzinie nauk ekonomicznych. W ciągu ostatnich pięćdziesięciu lat pojawiły się bowiem nowe poglądy ideowe w ekonomii i naukach o zarządzaniu, co wśród badaczy spowodowało zamęt twórczy i konflikt.

Celem niniejszego opracowania jest próba analizy istoty poznania naukowego i kanonów w nauce. Jest ono również próbą odpowiedzi na pytanie, od czego zależy rzetelny wynik procesów poznawczych. Najistotniejszą cechą poznania jest interdyscyplinarność, która umożliwia rozwój różnych dyscyplin nauki, prowadząc do: postępu cywilizacyjnego, rozwiązania problemu naukowego ${ }^{1}$ oraz zgłębienia relacji. W związku z tym, że ma charakter permanentny i posiada cechy uniwersalne, może stać się podstawa do innych badań. Cele procesu zgłębiania wiedzy są realizowane przy pomocy metody naukowej².

Autorzy zakładają, że stosowanie kanonów nauki i predyspozycje samego badacza wpływa na rzetelny wynik procesów poznawczych. Opracowanie obejmuje skrócona charakterystykę poznania naukowego i wybranych kanonów naukowości. Ma to za zadanie ułatwić ocenę naukowości rozwiązywanych problemów, zwłaszcza zjawisk gospodarczych i społecznych w zakresie nauk ekonomicznych.

\footnotetext{
${ }^{1}$ Powszechnym problemem naukowym, również w naukach ekonomicznych, jest prawda, a więc spodziewany efekt procesu badawczego. Wobec tego, prawda to wskaźnik oceny sprawności tego procesu i końcowy cel badań [Meredyk, 2015, s. 266].

${ }^{2}$ Metoda naukowa to ustalony, wystarczający zestaw zasad akceptowany przez naukową społeczność, który służy wskazaniu prawdziwości wysuwanych hipotez i uzyskaniu określonego zasobu wiedzy [Neal, Shone, 1982, s. 7-8].
} 


\section{Istota poznania naukowego}

Zdaniem K. R Poppera, poznanie nie rozpoczyna się od: obserwacji, gromadzenia faktów czy spostrzeżeń zmysłowych, ale od problemów. Oznacza to, że na początku powstaje napięcie między wiedzą a niewiedza. Bowiem nie ma problemów bez wiedzy ani wiedzy bez problemów. Każdy problem jest wynikiem odkrycia sprzeczności pomiędzy faktami a wiedzą [Popper, 1992, s. 120].

Problem posiada pierwotny charakter w procesie poznawczym. Natomiast treść problemu jest określona przez jego hipotetyczne rozstrzygnięcia. W początkowej fazie jest on niejasną ideą i należy go bliżej poznać przez krytykowanie go. Tylko w ten sposób można dojść do rozumienia problemu [Popper, 1974, s. 260].

Poznanie, rozumiane jako pozyskiwanie wiedzy o otaczającym świecie, zawiera zarówno akty (czynności), jak i rezultaty procesów poznawczych. Polega ono na: określaniu cech przedmiotów, ustalaniu nowych związków przyczynowo-skutkowych, a także relacji między badanymi zjawiskami. Wyrasta $z$ naturalnej potrzeby poznawczej człowieka i chęci zgłębiania dotychczasowej wiedzy [Ajdukiewicz, 2003, s. 17; Pelc, 2011, s. 18-20; Kiełczewski, 2009, s. 4-5]. Wyróżnia się dwa rodzaje poznania: naukowe ${ }^{3}$ i nienaukowe (potoczne), np. ze względu na: stopień użyteczności, pochodzenie lub inne cechy. Pierwsze jest efektem pracy badaczy wykorzystujących metody naukowe, precyzyjne środki i stosujących samokontrolę. Zależy ono od: wiedzy naukowca, sposobu wartościowania alternatyw i racjonalnego wykorzystania zdobytych informacji. Z kolei, poznanie nienaukowe jest nieprofesjonalne, powierzchowne, wynika z potrzeby życia codziennego. Zwiazane jest ono z brakiem zorganizowania, cechuje się spontanicznością, niedokładnościa, jak również subiektywnością [Prokopiuk, 2015].

Poznanie naukowe polega na odpowiednim doborze środków do celów badawczych i warunków ich realizacji. Zmierza ono do wykrywania ukrytych zjawisk i rozwiązania problemu badawczego [Meredyk, 2003, s. 50-53]. Proces ten jest podporządkowany złożonemu celowi i odbywa się w warunkach sprzyjających uzyskiwaniu ścisłej wiedzy. Jest ono dokonywane przy pomocy precyzyjnych pojęć i powinno być utrwalane w formie pisemnej. Zatem unika stosowania uproszczeń, wyrażania sądów pod wpływem emocji, jak i posługiwania się stereotypami [Kowalewska, 2007, s. 34].

Do elementów regulujących złożony proces zdobywania wiedzy zalicza się postawę badacza (dyspozycje psychiczne) i zabiegi instrumentalne, które łączą się z określonymi regułami. Składowe te zapewniają adekwatny, rzetelny i kompleksowy wynik poznawczy. Zasady tego postępowania mają charakter uniwersalny, co oznacza konieczność ich przestrzegania we wszystkich dyscyplinach i dziedzinach naukowych. W związku z tym, poznanie jako wieloetapowa procedura winno wyróżniać się następującymi cechami: intelektualną dociekliwościa, jednoznacznie sformułowanymi i zrozumiałymi kon-

\footnotetext{
${ }^{3}$ Demarkacjonizm to potrzeba odróżniania poznania naukowego od nienaukowego. Kluczową cechą poznania naukowego jest wyszukiwanie oryginalnego problemu wykraczającego poza dotychczasowy poziom wiedzy [Sawka, 2007, s. 160].
} 
kluzjami, twórczym charakterem i możliwością praktycznego zastosowania, postępowaniem opartym na uznanych zasadach (metodach badawczych) oraz ciagłym krytycyzmem wobec istniejącej wiedzy [Apanowicz, 2003, s. 22].

Budowanie naukowej wiedzy, w tym ekonomicznej, głównie odnosi się do zbierania wiedzy faktualnej i jej przetwarzania. Każdy badacz winien również mieć na uwadze wiedzę stworzona przez innych badaczy. Wynikiem przetworzenia przez niego wiedzy faktualnej jest uporządkowany i uzasadniony system twierdzeń ogólnych [Stachak, 1997, s. 9].

W przeszłości metodologia nauk była jednym z działów klasycznej logiki, tworzonym przez teoretyków poznania i logików. Do powstania ogólnej metodologii nauk jako autonomicznej dyscypliny przyczyniło się pojawienie potrzeby budowania wiedzy ścisłej i dążenie do oddzielenia nauk empirycznych od teorii epistemologicznych. Jest ona stosowana przez badaczy wszystkich dyscyplin naukowych. Natomiast szczegółowe metodologie (w ramach danej dyscypliny) w nauce były wynikiem badania zastosowań ogólnomedycznych zasad do rozwiazywania problemów i uogólnionych doświadczeń metodycznych. Przykładem może być metodologia nauk ekonomicznych [Stachak, 1997, s. 10].

Warto podkreślić, że poznanie może wiązać się z nowymi aspektami przedmiotu już wcześniej badanego lub przedmiotu jeszcze niebadanego. Badanie obejmuje określenie nowych cech przedmiotu, relacji bądź związków przyczynowych. Postęp w naukach, zwłaszcza ekonomicznych, polega na: rozpoznawaniu i uogólnianiu nowych faktów, modyfikacji problemów badawczych, lepszym uzasadnianiu twierdzeń czy nawet wykluczeniu twierdzeń fałszywych [Meredyk, 2003, s. 31-33].

Zaprezentowane powyżej cechy poznania wskazuja reguły postępowania i układ postaw badawczych. Oczywiście, układ ten nie jest ani ostateczny, ani pełny. W badaniach należy zapewnić samodzielność i margines swobody jako warunek oryginalności. W literaturze przedmiotu najczęściej wyodrębnia się dwa poziomy poznania: zmysłowe (obserwacji) oraz myślowe (abstrakcyjne). Pierwsze jest związane z pozyskiwaniem treści. Tymczasem drugie zachodzi bez zaangażowania zmysłów, a treści poznawcze sa: gromadzone, porządkowane i przekształcane [Kowalewska, 2007, s. 36-37].

Poznanie naukowe nie jest procesem dokonanym i może być punktem wyjścia do innych badań. Ze względu na źródła wiedzy wyróżnia się dwa jego typy (sposoby): samodzielne (bezpośrednie) i komunikatowe (pośrednie, znakowe), [Stachak, 1997, s. 7]. Poznanie samodzielne jest pierwotne (oryginalne) i oznacza uzyskanie wiedzy przez postrzeganie oraz myślenie abstrakcyjne. Dzieli się ono na: naukowe i nienaukowe. Pierwszy typ stanowi jedyne źródło oryginalnej wiedzy naukowej, wykonywanej metodycznie i ujmowanej w postaci tekstów. Z kolei, drugi typ odnosi się do osobistego doświadczenia, które codziennie występuje u wszystkich ludzi. Tymczasem poznanie komunikatowe polega na przekazywaniu wiedzy za pomoca znaków mowy od jej twórców do odbiorców [Stachak, 1997, s. 8].

Podsumowując, należy zauważyć, że dyspozycje adepta nauki i zabiegi instrumentalne mają istotny wpływ na rzetelny wynik poznania naukowego. Elementy te są uwarunkowane przez uniwersalne reguły naukowego postępowania. Natomiast proces poznania w nauce może być wstępem do dalszych badań [Apanowicz, 2003, s. 22-24]. 


\section{Cele poznania naukowego}

Celem poznania naukowego jest uzyskanie wiedzy ogólnej, a jednocześnie ścisłej i prostej. W nauce ma ono charakter złożony i opiera się na rezultatach poznania zmysłowego. Pierwszym jego krokiem jest poznanie myślowe. Polega ono na wyjaśnieniu istoty faktów dzięki wyodrębnieniu z nich tego, co ważne i przekształceniu w sądy i pojęcia. Poznanie naukowe kończy się wraz z rozwiązaniem określonego problemu, a jego rezultatem może być aspekt psychologiczny i społeczny. Jednak końcowym wynikiem rozważań w nauce winna być rzetelna ocena i interpretacja faktów oraz sądów [Apanowicz, 2005, s. 26].

Poznanie naukowe za sprawą aktywności człowieka i jego dążenia do zrozumienia rzeczywistości prowadzi do pogłębienia wiedzy o świecie. Dlatego jest ono związane z funkcjami wiedzy: teoretyczną, eksplanacyjną (wyjaśniająca), diagnostyczna, przewidująca (prognostyczna), praktyczną (pragmatyczna), [Stachak, 1997, s. 38].

Cele zewnętrzne procesu zdobywania wiedzy wynikaja z następujacych funkcji: wyjaśniającej, diagnostycznej, przewidującej lub pragmatycznej. Wiążą się one z rolą badania naukowego w świecie pozanaukowym i ze społeczną funkcją nauki. Cele wewnętrzne tego procesu zmierzają zaś do realizacji określonych cech badania naukowego i powinny być one spełnione, aby osiagnąć cele zewnętrzne. Zatem badanie, by zrealizować cele zewnętrzne, powinno wykazywać następujące właściwości: ogólność, bezstronność, oryginalność, indywidualność, ścisłość (adekwatność), logiczność, dialektyczność, pewność, prawdziwość [Kowalewska, 2007, s. 39].

Poznanie w nauce jest celowym i kilkuetapowym działaniem, które zostało określone zasadami, jak również procedurą badawczą. Powinny być one zgodne z metodami naukowymi, tak aby otrzymane rezultaty były adekwatne do badanej rzeczywistości. Wyniki tych badań muszą wskazywać na postęp w wiedzy, a także na możliwość ich wykorzystania w praktyce. Dlatego każdy naukowiec podczas zdobywania i zgłębiania wiedzy powinien cechować się: umiejętnością wyszukiwania intrygujących problemów, jasnością myślenia, systematycznością oraz obszerną wiedzą na temat przedmiotu badann ${ }^{4}$ w literaturze [Mazur, 1979, s. 14; Nadolna, 2009, s. 136].

\section{Rodzaje poznania naukowego}

Ważnymi składnikami procesu poznania są: poznanie myślowe, badania empiryczne oraz wyjaśnienie naukowe. Pierwszy element ma za zadanie objaśnić zjawisko. Drugi składnik sprawdza poznanie zmysłowe i abstrakcyjne w sposób eksperymentalny lub nieeksperymentalny. Odgrywa on ważną rolę podczas prognozowania badań naukowych przez: weryfikację hipotez, rozpoznanie cech danego fragmentu rzeczywistości, określenie zależności przyczynowo-skutkowych. Trzeci element kończy cała procedurę i dostarcza danych, których nie można uzyskać dzięki poznaniu abstrakcyjnemu i zmysłowemu. Jest

\footnotetext{
${ }^{4}$ Przedmiot badań w nauce odnosi się do faktu uwzględnionego w naukowym wyjaśnieniu danego problemu badawczego. Należy podkreślić, że zdefiniowany problem badawczy powinien harmonizować z przedmiotem badań [Poskrobko, 2009, s. 24; Meredyk, 2015, s. 269].
} 
on źródłem wiedzy instrumentalnej, potrzebnej do: planowania przedsięwzięć badawczych, rozpoznawania niewłaściwych zjawisk i wprowadzania wartości w pożądanych kierunkach [Apanowicz, 2000, s. 35-39].

We wszystkich dyscyplinach naukowych poznanie empiryczne można podzielić na badania: diagnostyczne i generalizujące. W pierwszym przypadku wykorzystuje się badania weryfikacyjne i heurystyczne. Badania weryfikacyjne wpływaja na przedmiot diagnozowany, a także pozwalają na wskazanie zależności przyczynowo-skutkowych. Weryfikacja zależności między zmiennymi a wskaźnikami przebiega w postaci rozumowania dedukcyjnego lub indukcyjnego. Badania weryfikacyjne sprawdzaja postawiona hipotezę. Z kolei, badania heurystyczne koncentrują się na odkrywaniu nieznanych i ważnych cech przedmiotu lub jego nowych właściwości [Kowalewska, 2007, s. 33].

Wyjaśnienie naukowe jest pewnego rodzaju sztuką zmierzającą do objaśniania wyznaczonego obszaru rzeczywistości ${ }^{5}$. Wyodrębnia się następujące jego typy: genetyczne, funkcjonalne, teleologiczno-funkcjonalne (celowościowe), logiczne. Wyjaśnienie genetyczne określa: przedmiot, zjawisko, instytucje. Wskazuje ono na przemiany w pewnym okresie, czynniki wywołujące zmiany, jak również okoliczności, w jakich doszło do powstania zjawiska. Jest ono właściwe również dla współczesnych procesów społecznogospodarczych, zwłaszcza podczas analizy między przyczynami a skutkami. Ten rodzaj rozumowania odwołuje się do: przeszłości, teraźniejszości oraz przyszłości [Apanowicz, 2003, s. 34].

Wyjaśnienie funkcjonalne zakłada, że zjawiska wzajemnie wpływają na swoje zmiany. Jest to szczególne sprzężenie wielokierunkowe, polegające na tym, że zmiana zjawiska A wpływa na zmianę zjawiska $B$, a ta zmiana wywołuje zmianę zjawiska A. Jednak nie uwzględnia ono przyczyn określonego zjawiska czy zdarzenia. Dlatego badania dąża do udowodnienia, że istnienie danej zależności jest wysoce prawdopodobne lub pewne. W naukach społecznych wykorzystuje się również wyjaśnienie teleologiczno-funkcjonalne wskazujące cel, do którego prowadzi określony proces. Polega ono na objaśnianiu faktów, zdarzeń przez formułowanie pytań: „po co istnieje określona instytucja?”, „po co zaszło zdarzenie A?”. Każde wyjaśnienie jest oparte na prawidłach logiki. Natomiast schemat logicznego wnioskowania pozwala wykorzystywać prawa logiczne lub schematy zadaniowe. Na przykład, jeżeli A jest większe od B, B jest większe od C, to A jest większe od C [Apanowicz, 2002, s. 35-37; Poskrobko, 2009, s. 22].

Dochodzenie do praw naukowych oraz twierdzeń w danej dziedzinie wiedzy to przede wszystkim proces etapowy. Wyniki poznania są realizowane dzięki następującym operacjom myślowym: analiza, synteza, dedukcja, indukcja, porównanie, przeciwstawienie, uogólnienie, wnioskowanie (tabela 1.).

\footnotetext{
${ }^{5}$ Popper stwierdził, że rozważając problem rzeczywistości, nie można ustrzec się refleksji. Jego zdaniem, najważniejsza jest teoria istnienia (realności materii). Natomiast kluczowym problemem dzisiejszego człowieka jest to, żeby świat ochronić przed zgubą [Popper, Eccles, 1977, s. 9].
} 
TABELA 1.

Rodzaje metod i procesów poznania naukowego

\begin{tabular}{|c|c|}
\hline Metody naukowe & Procesy poznania naukowego \\
\hline analiza i synteza & porównanie i przeciwstawienie \\
\hline dedukcja i indukcja & uogólnienie i wnioskowanie \\
\hline
\end{tabular}

Źródło: opracowanie własne na podstawie: [Apanowicz, 2002, s. 25].

Analiza (rozbiór) to proces myślowy, który w naukach empirycznych ma za zadanie wykrycie struktury i mechanizmu działania. Polega ona na rozdzieleniu danej całości na elementy składowe, które są rozpatrywane osobno. Zatem, rozwiązując problem naukowy, należy rozłożyć go na tyle elementów, na ile jest to możliwe po to, aby można było zgłębić jego istotę [Apanowicz, 2002, s. 24].

Analiza ekonomiczna to również metoda badania naukowego. Polega ona na podzieleniu całości za pomocą logicznej abstrakcji. Może zostać przeprowadzona w odniesieniu do poznania naukowego lub celów praktycznych jako zasadniczy element podejmowania decyzji gospodarczych. W 1637 roku Rene Descartes opublikował dzieło pt.: Rozprawa o metodzie właściwego kierowania rozumem i poszukiwania prawdy w naukach, w którym ukazał poznawczą rolę analizy. Według niego, podczas badania problemów powinny obowiązywać następujące zasady: pewność (prawdziwe jest tylko to, co jest niewątpliwe, pozyskane bez pośpiechu i uprzedzeń), analiza (uzyskanie najkorzystniejszego rozwiązania w wyniku dzielenia zagadnienie na tyle części, ile trzeba), synteza (stopniowe przechodzenie od elementów prostych do uzyskania wiedzy ogólnej), kontrola (sprawdzenie, czy nie pominięto ważnych czynności badawczych), [Stachak, 1997, s. 200].

W literaturze przedmiotu do badania organizacji gospodarczych wykorzystuje się analizę dynamiczną i statystyczną. Pierwsza ma za zadanie wyszukiwać zależności między zjawiskami gospodarczymi. Z kolei, druga odnosi się do badania poszczególnych czynników gospodarczych (kosztów, wyników gospodarowania). W ten sposób można ustalić zależności i ich siłę oddziaływania [Sawka, 2007, s. 162-163].

Synteza (zestawienie) jako zabieg myślowy wiąże się ze scalaniem: czynników, parametrów, relacji określonego problemu, organizacji, struktury itp. Za sprawą operacji myślowych, takich jak: uogólnienie czy porównywanie dąży się do wykrywania istotnych, kluczowych relacji i związków w nowej całości. Zatem zarówno proces syntezy, jak i analizy stanowi zamkniętą całość i swoista jedność. Synteza wykorzystuje abstrahowanie i porównanie. Dlatego głównym jej zadaniem jest uogólnienie informacji uzyskanych na podstawie danych empirycznych lub łączenie elementów wiedzy na określony temat. Jej etap końcowy polega na wyodrębnieniu nowej całości dzięki najważniejszym cechom wcześniej analizowanych faktów naukowych [Apanowicz, 2002, s. 24].

Dedukcja (wyprowadzenie) jest rozumowaniem logicznym, wnioskowaniem o niektórych elementach lub przedmiotach z danej całości. Obejmuje przechodzenie od ogółu do szczegółu. Dzieli się na bezpośrednią (konkluzja jest wyprowadzona z jednej 
przesłanki) oraz pośrednią (opartą na kilku przesłankach). W związku z tym, prowadzi ona do konkluzji i jednocześnie nie wymaga implikowania nowych definicji lub twierdzeń [Stachak, 1997, s. 175].

Indukcja (wprowadzenie) to zabieg myślowy, który polega na wyprowadzeniu uogólnień na podstawie obserwacji faktów lub eksperymentów. Odwrotnie aniżeli dedukcja jest ona rozumowaniem od szczegółu do ogółu. Na podstawie wiadomości o zjawiskach danej klasy można wnioskować o wszystkich zjawiskach tam znajdujących się. Dlatego wnioskowanie indukcyjne jest ważnym narzędziem w naukach empirycznych [Bocheński, 1992, s. 103].

Analogia jest procesem pośrednim między dedukcją a indukcja. Wiąże się ona z przenoszeniem podobieństwa wartości z jednego przedmiotu na drugi. Przedmiot posiada określone cechy, podobne do cech w innych przedmiotach [Apanowicz, 2002, s. 29].

Porównanie stanowi proces myślowy w badaniach naukowych. Dotyczy ono zestawienia ze sobą cech zjawisk, w celu znalezienia różnych lub wspólnych właściwości. Można porównać bądź zestawić ilościowe i jakościowe wyniki badań z daną skalą odniesienia, np.: modelem teoretycznym, normatywem obowiązującym w organizacji. Wybór skali porównawczej jest związany z celem badania naukowego. Wobec tego, porównania są to istotne i kluczowe czynności poznawcze występujące na wszystkich etapach pracy badawczej. Ich przeciwstawienie to konfrontacja mysli, pojé́, faktów lub procesón [Apanowicz, 2000, s. 27].

Uogólnienie polega na teoretycznym czy praktycznym scaleniu rozłożonych części w całość, które w kompleksowym ujęciu pozwala na sformułowanie nowych twierdzeń. Z kolei, wnioskowanie jest procesem myślowym pozwalającym na wyprowadzanie oryginalnych wniosków zgodnie z prawem logiki. Jego zadaniem jest zwarte określenie najważniejszych wyników przeprowadzonych badań, a podstawą tego procesu są udokumentowane dane. W związku z tym, przejrzyste wnioskowanie powinno cechować się: praktycyzmem, wnikliwościa, a szczególnie dużą ostrożnością [Apanowicz, 2002, s. 31].

Należy również mieć na uwadze dużą ilość potencjalnych podejść badawczych w ekonomii. Bowiem można ja uprawiać na podstawie: podejścia holistycznego (czerpanie z dorobku innych dyscyplin naukowych niż ekonomia i postrzeganie danej teorii w aspekcie szerszego systemu teorii naukowych), podejścia empirycznego (tworzenie systemu zdań na podstawie doświadczeń, skupionego na badaniach empirycznych i poszukiwaniu prawidłowości), tradycyjnego, racjonalnego modelu wiedzy naukowej (uzasadnienie zdefiniowanych tez), racjonalizmu krytycznego (poszukiwanie nowych teorii, które lepiej zinterpretują badaną rzeczywistość; zmierzanie w kierunku falsyfikacji hipotez i teorii naukowych). Wybór właściwego podejścia jest uzależniony od: indywidualnych preferencji samego badacza, wykorzystywanej przez niego metodologii i prawdy [Kiełczewski, 2009, s. 12-13].

\section{Kanony nauki}

Każda dziedzina nauki czerpie z ogólnych kanonów i jednocześnie kreuje własne ramy pojęciowe, które ułatwiają ocenę naukowości rozwiązywanych problemów. Nauka 
polega na tworzeniu: twierdzeń, hipotez, teorii lub praw naukowych na podstawie wiedzy o rzeczywistości [Poskrobko, 2011, s. 1]. Najczęściej jest ona określana jako wyspecjalizowana działalność poznawcza, która dąży do obiektywnego poznania natury $\mathrm{i}$ istoty świata w konkretnych warunkach społecznych. Pojęcie nauka jest również rozumiane jako badanie naukowe mające na celu poznanie określonych aspektów rzeczywistości oraz systemu wiedzy o społeczeństwie i zjawiskach gospodarczych [Kuc, 2012, s. 20].

Nauka pod względem przedmiotowym dzieli się na trzy grupy, ti.: nauki przyrodnicze, techniczne i społeczne. Do nauk społecznych zalicza się ekonomię, która głównie koncentruje się na zachowaniach człowieka w społeczeństwie. Ekonomista bada zachowanie się ludzi, swoje własne i na tej podstawie formułuje wnioski [Poskrobko, 2009, s. 18; Żukowski, 2009, s. 13].

Naukę jako wiedzę racjonalną należy komponować zawsze zgodnie z przyjętymi kanonami. Pojęcie kanon naukowy odnosi się do zbioru zasad o elementarnym znaczeniu dla poznania i prowadzenia badań naukowych. Podstawowe kanony wskazujące, jak zorganizować proces badania naukowego, to: paradygmaty nauki, aksjomaty, prawa nauki, kategorie naukowe, teorie i teorematy [Poskrobko, 2013, s. 12].

Pojęcie paradygmatu jako wiodącego i najbardziej elastycznego kanonu naukowego określił Thomas S. Kuhn. Przedstawił on wąskie i szerokie jego ujęcie. Pierwszy aspekt oznacza określony model (wzorzec) rozwiazania problemów w danej dyscyplinie naukowej. Z kolei, drugie ujęcie odnosi się do szablonu, który kieruje nastawieniem wszystkich uprawiających określoną dziedzinę wiedzy. Podstawowa cecha koncepcji T. S. Kuhna to zaznaczenie rewolucyjnego charakteru postępu naukowego. Paradygmatami autor nazywa osiagnięcia (zbiór, zestaw poglądów), które określona grupa badaczy akceptuje i traktuje jako podstawę swojej praktyki. Akceptowane wzory współczesnej praktyki naukowej budują spójny model tradycji badań w nauce. Ukształtowanie się paradygmatu oraz bardziej wyspecjalizowanych badań jest wyrazem dojrzałości określonej dyscypliny [Kuhn, 1985, s. 411; Kiełczewski, 2009, s. 11].

Uczeni, formułując i rozwijając paradygmat, chcą wyjaśnić zachowanie różnorodnych aspektów realnego świata [Kuhn, 2015, s. 43-50; Meredyk, 2009, s. 36]. Dojrzała nauka opiera się na jednym paradygmacie. Można wskazać jego typowe, zasadnicze elementy, takie jak: ogólne reguły kierujące pracą w obszarze paradygmatu, typowe sposoby wykorzystywania podstawowych praw w różnych sytuacjach teoretycznych, jasno zdefiniowane założenia teoretyczne, techniczne sposoby odnoszenia praw paradygmatu do realnego świata [Kuhn, 1970, s. 5-9; Chalmers, 1997, s. 123].

Lakatos paradygmaty T. S. Kuhna określił jako programy badawcze i wyodrębnił kilka takich struktur. Zaliczył do nich wyrażenia zdaniowe i wyrażenia nazwowe (terminy teoretyczne). W zbiorze tych wyrażeń wyróżnił on: super-teorie, maxi-teorie (programy badawcze, tradycje, tematy badawcze, paradygmaty), prawa, hipotezy, teorie oraz zdania spostrzeżeniowe [Hajduk, 2011, s. 130].

$\boldsymbol{A} \boldsymbol{k s j o m a t}$ (pewnik) to twierdzenie (założenie) uznane za prawdziwe i nie wymagające dowodów. Twierdzenia w nauce opisują zjawiska językiem naukowym [Poskrobko, 2013, s. 13]. 
Prawa nauki są dostatecznie zweryfikowanymi twierdzeniami ogólnymi, które ukazują powszechne prawidłowości, a także relacje między zjawiskami zachodzącymi w świecie [Encyklopedia PWN, 2015]. Mogą one występować w formie: zdań ogólnych (prawa nauki ogólne) lub ogólnych w przybliżeniu (prawa nauki statystyczne). Pierwsze z nich definiują stałe związki określonych zjawisk. Natomiast drugie ustalają współwystępowanie zjawisk z określonym prawdopodobieństwem. Wobec tego, prawa nauki ułatwiają poznanie, jak również prognozowanie przyszłych procesów i zjawisk [Poskrobko, 2009, s. 19].

Ekonomia, podobnie jak inne nauki, wykorzystuje specyficzne narzędzia i metody do badania prawidłowości i mechanizmów rozwoju społeczno-gospodarczego [Wilkin, 2009, s. 295-296]. Ze względu na swój charakter jest ona nauką teoretyczna. Oznacza to, że ekonomia opisuje określone zdarzenia, fakty i relacje działań ludzi. Jeżeli te relacje są stałym elementem procesu społeczno-gospodarczego, to traktuje się je jako prawidłowości ekonomiczne. Stanowią one powiązania, które istnieją w realnej rzeczywistości gospodarczej [Żukowski, 2009, s. 22-23].

Można wskazać i wyróżnić prawa ekonomiczne zarówno o charakterze uniwersalnym, jak i ponadczasowym. Dotyczą one poszczególnych jednostek i zbiorowości ludzkich. Zagregowany efekt działania różnych prawidłowości wpływa na dążenie uczonego do upraszczania oraz modelowania badanych zjawisk i procesów. Wobec tego, prawa ekonomiczne formułuje się jako ogólne prawidłowości opisujące procesy gospodarcze, do których zalicza się: produkcję, podział, wymianę, konsumpcję [Żukowski, 2009, s. 23-24].

Prawa ekonomiczne posiadają cechy, które odróżniaja je od praw przyrody. Niektóre $z$ nich funkcjonuja tylko w ściśle określonych warunkach. Ponadto, prawa ekonomiczne są obiektywne. Oznacza to, że są niezależne od świadomości ludzi i są rzeczywistą cechę procesu gospodarczego. Oddziaływanie na prawa ekonomiczne może być tylko pośrednie. To zmiana wyznaczonych parametrów będzie determinowała przebieg procesów gospodarczych i praw ekonomicznych. Przykładem może być efektywność polityki gospodarczej państwa [Meredyk, 2003, s. 28-29].

Kategorie naukowe to ogólne pojecia, za pomoca których w filozofii i nauce ujmowana jest ręecsynwistość [Stownik, 2015]. W nauce stanowią one kluczowe węzły, które łączą pojęcia z różnych obszarów badawczych. Każda kategoria jest pojęciem, ale nie każde pojęcie będzie kategoria. W takim razie kategoria ekonomiczna jest pojęciem abstrakcyjnym, które wyraża ogólne własności różnych aspektów procesu gospodarczego [Żukowski, 2009, s. 24-25; Dach, 2015].

Na proces gospodarowania składają się powtarzane działania podmiotów gospodarczych, odbywające się w zmiennych warunkach. Pomiędzy tymi działaniami pojawią się różne zależności. Ekonomia przy pomocy określonych metod (oceny faktów, danych statystycznych, obserwacji) wskazuje, które z tych zależności można uznać jako ogólne prawidłowości w procesie. W ten sposób tworzą się abstrakcyjne pojęcia, te natomiast definiuje się jako kategorie ekonomiczne. Wyznaczają one sens opisywanego zjawiska, a przykładem może być: cena, zysk, procent czy dochód [Meredyk, 2003, s. 24].

Teoria naukowa jest definiowana jako zespół pojęć i twierdzeń, które objaśniaja określoną dziedzinę zjawisk i procesów na podstawie naukowych faktów oraz praktyki 
[Meredyk, 2003, s. 30-31]. Teoria naukowa to system pojęć połączonych strukturami logicznymi (dyrektywy logiczne, wymogi pragmatyczne), który jest: uporządkowany, niesprzeczny, obiektywny, a głównie innowacyjny. Zasadniczym jej zadaniem jest badanie rzeczywistości, a przez to umożliwienie człowiekowi poznania realnego świata, jego budowy i zasady rozwoju. Pozwala ona racjonalizować ludzką aktywność naukowa, czyli diagnozować i prognozować [Apanowicz, 2000, s. 41-42; Meredyk, 2003, s. 94-100; Keller, 2007, s. 25].

Teorie ekonomiczne stanowią rezultaty pracy teoretyków w dziedzinie nauk ekonomicznych. Przede wszystkim objaśniaja one rzeczywistość gospodarcza i ukazuja abstrakcyjny obraz przebiegu procesów w gospodarce. Konieczne wydaje się przyjęcie założeń upraszczających po to, aby opis danego fragmentu gospodarki był zrozumiały. W ten sposób badacz uchwyci to, co jest kluczowe i wymaga teoretycznego wyeksponowania [Z̈ukowski, 2009, s. 25].

Twierdzenia naukowe, jeżeli pełnią funkcję wyjaśniającą zjawiska, są definiowane jako teorie i koncepcje naukowe [Meredyk, 2003, s. 47]. Jeśli odnoszą się do funkcji predykcji, czyli możliwości prognozowania zjawisk, są one nazywane teoriami naukowymi. Podstawowe ich zadanie polega na wyjaśnianiu aspektów rzeczywistości. O teorii naukowej mówi się w sytuacji, gdy kilka podobnych praw dotyczy tych samych procesów. Powinna ona zawierać prognozy zgodne $\mathrm{z}$ aktualną wiedza, a także być falsyfikowana, czyli musi istnieć wyjaśnienie umożliwiające wskazanie, że teoria jest błędna. W celu właściwego tworzenia teorii jest potrzebna metoda ${ }^{6}$ określana jako racjonalny sposób postępowania.

W naukowych tekstach ekonomicznych spotyka się twierdzenia wymagające uzasadnienia przez samego badacza i takie które nie wymagaja żadnego uzasadnienia. Pierwsze są kluczowe, ponieważ wynikają z badań własnych, zaś drugie mogą odgrywać rolę pomocniczą w badaniach ekonomicznych. Twierdzenia ekonomiczne są udowadniane pośrednio i bezpośrednio. Pierwsze uzasadnienie to odwołanie się do twierdzeń innych badaczy. Drugie uzasadnienie może być terminologiczne (w stosunku do własnych hipotez przyjętych konwencji) lub empiryczne (wynikające z obserwacji naukowca), [Stachak 1997, s. 19-20].

\section{Podsumowanie}

Nauka jest procesem zdobywania wiedzy o świecie oraz sposobem realizacji potrzeby poznawczej i ciekawości człowieka. Główne jej zadanie to budowanie czegoś nowego i poszukiwanie drogi do prawdziwej wiedzy. Proces poznania naukowego polega na ustalaniu związków przyczynowo-skutkowych i określaniu właściwości przedmiotów, zjawisk oraz relacji. Jest on wynikiem: własnego talentu badacza, jego kreatywności, wiedzy ogólnej i stosowanych metod naukowych. Rzetelny wynik poznawczy zależy od postawy naukowca i przestrzegania uniwersalnych zasad wykorzystywanych

${ }^{6}$ Zatem metoda może być wiarygodna jedynie pray zatożeniu, że w prayrodżie nystępuja jakieś prawidtowości [Grobler, 2006, s. 28-29]. 
we wszystkich dziedzinach nauki. Operacje myślowe, wpływające na rezultaty poznania naukowego, to: analiza (podział danej całości na elementy i wykrywanie mechanizmu ich działania), synteza (np. scalanie czynników danej struktury), dedukcja (wyprowadzenie od ogółu do szczegółu), indukcja (wyprowadzenie od szczegółu do ogółu), porównanie (poszukiwanie wspólnych lub różnych cech), uogólnienie (łączenie w całość i tworzenie nowych twierdzeń), wnioskowanie (wyprowadzanie wniosków według praw logiki).

Nauka jest wiedzą racjonalną, opartą na ogólnych kanonach, czyli zbiorze reguł o podstawowym znaczeniu dla poznania naukowego. Kanony nauki maja kluczowe znaczenie również dla prowadzenia procesu badania naukowego. Korzystanie z kanonów i metod naukowych powoduje, że działania twórcze mają charakter naukowy. Wydaje się, że wynik procesów poznawczych jest zależny od: zbioru kanonów, dyspozycji badacza i jego wiedzy ogólnej. Należy także podkreślić, że celem kilkuetapowego poznania naukowego jest rozwiązanie problemu badawczego. Natomiast postawa samego badacza powinna być skierowana w stronę przestrzegania uniwersalnych reguł przyjętych w nauce. Niestety, zarówno zasady naukowego postępowania, jak i dyspozycje naukowca tworzą układ, który nie jest pełny.

\section{Wkład autorów w powstanie artykułu}

dr hab. Adam Sadowski, prof. UwB - opracowanie wstępu, zakończenia, streszczenia, edycja formalna i merytoryczna $-25 \%$

mgr Anna Szydlik - dobór literatury i opracowanie teksu głównego artykułu - 75\%

\section{Literatura}

Ajdukiewicz K., 1985, Jezyłk i poznanie, Państwowe Wydawnictwo Naukowe, Warszawa. Ajdukiewicz K., 2003, Zagadnienia i kierunki filozofii, Wydawnictwo Antyk, Warszawa. Apanowicz J., 2000, Metodologiczne elementy procesu poznania naukowego w teorii organizacji $i$ zarzadzania, Wydawnictwo Diecezji Pelplińskiej Bernardinum, Gdynia.

Apanowicz J., 2002, Metodologia ogólna, Wydawnictwo Diecezji Pelplińskiej Bernardinum, Gdynia.

Apanowicz J., 2003, Metodologia nauk, Dom Organizatora, Toruń.

Apanowicz J., 2005, Metodologiczne uwarunkowania pracy naukowej, Wydawnictwo Difin, Warszawa.

Bocheński J. M., 1992, Wspótczesne metody myślenia, Wydawnictwo „W drodze”, Poznań.

Chalmers A. F., 1997, Czym jest to, co zwiemy nauka, Wydawnictwo Siedmiogród, Warszawa.

Dach Z., 2007, Mikroekonomia dla studentów, Wydawnictwo Naukowe SYNABA, Kraków, http://cytaty.mfiles.pl/index.php/keyword/3626/0/kategoria_ekonomiczna (data wejścia: 12.03.2015).

Einstein A., 1999, Pisma filozoficzne, tłum. K. Napiórkowski, Instytut Filozofii i Socjologii PAN, Warszawa. 
Encyklopedia PWN, http://encyklopedia.pwn.pl/haslo.php?id=3961800 (data wejścia: 12.03.2015).

Grobler A., 2006, Metodologia nank, Wydawnictwo Aureus, Wydawnictwo Znak, Kraków.

Hajduk Z., 2011, Ogólna metodologia nauk, Wydawnictwo Katolickiego Uniwersytetu Lubelskiego, Lublin.

Keller A., 2007, Nauka jako wytwór cztowieka, [w:] Doktoranci o metodologii nank ekonomicznych, K. Kuciński (red.), Oficyna Wydawnicza Szkoły Głównej Handlowej, Warszawa.

Kiełczewski D., 2009, Ewolucja modeli uprawomocniania wiedsy naukowej a metodologii nauk. ekonomicznych, „Optimum. Studia Ekonomiczne”, nr 4 (44).

Kowalewska R., 2007, Istota poznania naukowego, [w:] Doktoranci o metodologii nauk ekonomicznych, K. Kuciński (red.), Oficyna Wydawnicza Szkoły Głównej Handlowej, Warszawa.

Kuc B. R., 2012, Funkecje nauki. Wstep do metodologii, Wydawnictwo TPM, Warszawa.

Kuhn T. S., 1985, Dwa bieguny, tradycja i nowatorstwo w badaniach naukonych, Wydawnictwo Naukowe PWN, Warszawa.

Kuhn T. S., 1970, Logic of discovery or Psychology of Research, [in:] Criticism and Growth of Knowledge, Lakatos I., Musgrave A. (eds.), Cambridge University Press.

Kuhn T. S., The priority of paradigms, http://projektintegracija.pravo.hr/_download/repository/Kuhn_Structure_of_Scientific_Revolutions.pdf (data wejścia: 12.03.2015).

Mazur M., 1979, Historia naturalna polskiego naukowca, Państwowy Instytut Wydawniczy, Warszawa.

Meredyk K., 2003, Przedmiot i metoda nauk ekonomicznych, Wydawnictwo Uniwersytetu w Białymstoku, Białystok.

Meredyk K., Struktura projektu naukowego, http://mikroekonomia.net/system/publication _files/330/original/25.pdf?1314952665 (data wejścia: 12.03.2015).

Meredyk K., 2009, Wspótczesna metoda nank ekonomicznych w ujecin aplikacyjnym, „Optimum. Studia Ekonomiczne", nr 4 (44).

Motycka A., 2005, Rozum i intuicja w nauce, Wydawnictwo ENETEIA, Warszawa.

Nauka i potrzeby jej żmian, http://www.zb.eco.pl/bzb/1/nauka.htm (data wejścia: 12.03.2015).

Neal F., Shone R., 1982, Proces budowania modeli ekonomicznych, Wydawnictwo Naukowe PWN, Warszawa.

Nadolna B., 2009, Metodologiczne aspekty prac naukonych z zakresu nauk ekonomicznych, „Oeconomica”, nr 273 (56).

Pelc M., 2011, Elementy metodologii badań naukonych, Wydawnictwo Akademii Obrony Narodowej, Warszawa.

Poskrobko B., 2011, Metodologiczne aspekty ekonomii zrównoważonego rožoju, [w:] Ekonomia zrównoważonego rozwoju w świetle kanonów nauki, B. Poskrobko (red.), Wydawnictwo Wyższej Szkoły Ekonomicznej w Białymstoku, Białystok 2011.

Poskrobko B., 2009, Nanka i nankowość w ekonomii $i$ zarzadzaniu, „Optimum. Studia Ekonomiczne", nr 4 (44). 
Poskrobko B., 2013, Paradygmat zrównoważonego rozwoju jako wiodacy kanon w badaniu nowych obszarów ekonomii, „Ekonomia i Środowisko”, nr 3 (46).

Popper K. R., 1992, Logika nauk społecznych, „Acta Universitatis Wratislaviensis”, no. 1317, Prace filozoficzne, LXXI, Wrocław.

Popper K. R., 1974, Objective Knowledge. An Evolutionary Approach, Clarendon Press, London.

Popper K. R., Eccles J. C., 1977, The Self and Its Brain. An Argument for Interactionism, Routledge Taylor \& Francis Group, London and New York.

Prokopiuk J., Nauka i potræ̌eba jej przemiany, BZB, nr 1, „Ekorozwój 2020”.

Sawka R., 2007, Kameralne metody badan naukowych, [w:] Doktoranci o metodologii nauk ekonomicænych, K. Kuciński (red.), Oficyna Wydawnicza Szkoły Głównej Handlowej, Warszawa.

Stachak S., 1997, Wstęp do metodologii nauk ekonomicznych, Wydawnictwo „Książka i Wiedza", Warszawa.

Stownikjezylka polskiego, http://sjpd.pwn.pl/haslo/inteligencja/ (data wejścia: 12.03.2015).

Stownik jezyka polskiego, http://sjp.pwn.pl/szukaj/kategoria (data wejścia: 12.03.2015).

Wilkin J., 2009, Czy ekonomia może być piekna? Rozważania o przedmiocie i metodzie ekonomii, „Ekonomista”, nr 3.

Żukowski M., 2009, Ekonomia. Zarys wykładu, Wydawnictwo Uniwersytetu M. CurieSkłodowskiej, Lublin. 